\title{
Łukasz Kozłowski
}

Szczecin

\section{Zawieranie małżeństw na przedmieściach Szczecina w świetle akt stanu cywilnego z obwodu USC Gumieńce w latach 1875-1906}

\section{Część I. Roczne liczby małżeństw i sezonowość małżeństw}

Od lat siedemdziesiątych XX wieku, gdy nastąpił w Polsce znaczny rozwój metod badawczych w dziedzinie demografii historycznej, opublikowano dziesiątki badań opartych na analizie danych nominatywnych. Badania metodą agregatywną i rekonstrukcji rodzin pozwoliły odtworzyć obraz ludności zamieszkującej w przeszłości miasta i wsie leżące w dzisiejszych granicach Polski, jak również zobrazować procesy zmieniające charakter tych lokalnych społeczności. W wyniku analiz opartych na danych z ksiąg metrykalnych i akt stanu cywilnego udało się między innymi zrekonstruować struktury społeczne osiemnastowiecznej Warszawy, dziewiętnastowiecznego Rzeszowa i Opola, a także szeregu miejscowości na Śląsku i na Pomorzu. W świetle tego dorobku naukowego niekorzystnie przedstawia się sytuacja Pomorza Zachodniego, gdzie dopiero w ostatnich latach dostrzeżono celowość sięgnięcia po dane indywidualne dotyczące ewangelickiej ludności narodowości niemieckiej zamieszkującej ten region do zakończenia II wojny światowej. Przez wiele lat demografia historyczna Pomorza Zachodniego ograniczała się przede wszystkim do analizy zbiorczych niemieckich statystyk urzędowych ${ }^{1}$. Na podstawie danych sumarycznych, jakkolwiek przydatnych

\footnotetext{
${ }^{1}$ Syntetyczne opracowanie danych demograficznych na podstawie pruskiej statystyki Pruskiego Biura Statystycznego (Königlich Preußisches Statistisches Bureau) przedstawia niedawna
} 
w odtwarzaniu globalnych procesów demograficznych, takich jak poszczególne etapy transformacji demograficznej, nie sposób opisać lokalne struktury społeczne, kręgi towarzyskie czy chociażby regionalne zwyczaje.

Pierwszą próbą wykorzystania parafialnych ksiąg metrykalnych w badaniach agregatywnych nad ludnością Pomorza Zachodniego była opublikowana w 2007 roku w „Przeszłości Demograficznej Polski” praca opisująca statystykę ślubów w ewangelickiej parafii Jasienica z lat 1778-1880². Podobnych badań na podstawie przedwojennych niemieckich akt stanu cywilnego dotychczas na Pomorzu Zachodnim nie prowadzono. Baza źródłowa jest natomiast niezwykle bogata i umożliwia przeprowadzenie szerokich badań demograficznych dotyczących zarówno ludności największych miast regionu (łącznie ze Szczecinem), jak i zachodniopomorskich wsi. Prowadzone skrupulatnie przez niemieckich urzędników księgi stanu cywilnego zachowały się do dziś w bardzo dobrym stanie i są dostępne w Archiwum Państwowym w Szczecinie oraz w archiwach urzędów stanu cywilnego.

Motywacją do podjęcia badań nad ludnością zamieszkującą przedmieścia Szczecina na przełomie XIX i XX wieku była zatem przede wszystkim bogata baza źródłowa, umożliwiająca odtworzenie struktury demograficznej badanej społeczności i porównanie jej z opisanymi wcześniej strukturami demograficznymi ludności polskiej. Uzasadnieniem dla podjęcia badań stała się również możliwość rzucenia nowego światła na zagadnienia demografii historycznej Pomorza Zachodniego i przetarcia szlaku dla dalszych, pogłębionych badań społeczno-demograficznych pozwalających poszerzyć wiedzę na temat społeczeństwa Pomorza Zachodniego na przełomie XIX i XX wieku.

Badania, do których nawiązuje niniejszy artykuł, przeprowadzono na podstawie danych jednostkowych z akt małżeństw urzędu stanu cywilnego Gumieńce (Scheune). Chronologiczny zakres badań obejmował lata 1875-1906, z wyłączeniem roku 1904. Początek tego okresu wyznacza wprowadzenie urzędów stanu cywilnego w Prusach. Rok 1904 został pominięty ze względu na brak danych³ . W trakcie przeprowadzania badań akta małżeństw zawartych po 1907 roku nie

publikacja Dariusza K. Chojeckiego, Od społeczeństwa tradycyjnego do nowoczesnego. Demografia i zdrowotność głównych ośrodków miejskich Pomorza Zachodniego w dobie przyspieszonej industrializacji i urbanizacji w Niemczech (1871-1913), Szczecin 2014.

${ }^{2}$ Radosław Gaziński, Agnieszka Gut, Paweł Gut, Dariusz Szudra, Maciej Szukała, Śluby w ewangelickiej parafii Jasienica pod Szczecinem w latach 1778-1880, PDP 28, 2007. Jak wykazali autorzy, mimo odmiennej narodowości i wyznania, a także osobliwej struktury społeczno-gospodarczej, społeczność tej położonej nad Zalewem Szczecińskim miejscowości nie różniła się pod względem zachowań małżeńskich od ludności innych regionów, gdzie przeprowadzono wcześniej podobne badania.

${ }^{3} \mathrm{~W}$ momencie rozpoczęcia badań księga małżeństw z 1904 nie znajdowała się w zasobie Archiwum Państwowego w Szczecinie. 
były jeszcze przekazane do Archiwum Państwowego - znajdowały się w zasobie archiwum Urzędu Miasta Szczecina. Ustalenie granicy chronologicznej miało zatem przede wszystkim charakter praktyczny.

W badanym okresie Gumieńce były niewielką miejscowością sąsiadującą bezpośrednio ze Szczecinem (dziś stanowią dzielnicę miasta). Podobnie jak pozostałe miejscowości wchodzące w skład ówczesnego obwodu urzędu stanu cywilnego (zwłaszcza Pomorzany), Gumieńce były częścią miejskiej aglomeracji Szczecina, a ludność zamieszkująca tę wieś - ze względu na styl życia oraz charakter wykonywanej pracy - mogła być nazywana ludnością przedmieść Szczecina. Druga połowa XIX wieku to okres, w którym leżące wokół Szczecina typowe osady wiejskie zaczęły przekształcać się w podmiejskie osiedla, późniejsze dzielnice miasta, przy czym urbanizacja, rozwój infrastruktury komunikacyjnej i wzajemnych powiązań gospodarczych następowały w poszczególnych miejscowościach w różnym tempie.

Głównym celem badań było uchwycenie procesu przemian demograficznych towarzyszących rozwojowi społeczno-gospodarczemu przedmieść Szczecina, a także ukazanie skutków przyspieszonej urbanizacji i industrializacji podszczecińskich Pomorzan w porównaniu z miejscowościami, w których zmiany te zachodziły w znacznie wolniejszym tempie (Gumieńce, Mierzyn) lub nie zachodziły wcale (Stobno) ${ }^{4}$. Najważniejsze pytania, jakie postawiono przed rozpoczęciem badań, to:

1. Jaki wpływ na strukturę demograficzną ludności miały przemiany społeczno-gospodarcze przedmieść Szczecina, napływ ludności wiejskiej, uprzemysłowienie, budowa osiedli robotniczych?

2. Jakie różnice $\mathrm{w}$ strukturze demograficznej można zaobserwować w poszczególnych miejscowościach objętych badaniem ze szczególnym uwzględnieniem charakterystyki społeczno-gospodarczej tych miejscowości?

3. Jakie różnice można zaobserwować w charakterystyce demograficznej ludności przedmieść Szczecina w porównaniu z dotychczasowymi badaniami w zakresie demografii historycznej ludności polskiej.

Opracowując indywidualne dane statystyczne zawarte w aktach stanu cywilnego, posłużono się agregatywną metodą badawczą. Dane pozyskane z ksiąg

\footnotetext{
${ }^{4} \mathrm{Na}$ podstawie tych badań opublikowano wcześniej artykuł przedstawiający przekrój społeczno-zawodowy okręgu USC Gumieńce. Wyróżniono pięć zasadniczych grup zawodowych, w tym najliczniejszych: robotników (62\% nupturientów), rzemieślników (18\%), właścicieli i handlowców (5\%), urzędników i inteligencję (1\%), pozostałe zawody (6\%). Zob. Łukasz Kozłowski, Przekrój społeczno-zawodowy przedmieść Szczecina w latach 1875-1906 na podstawie akt matżeństw Urzędu Stanu Cywilnego w Gumieńcach, „Szczeciński Informator Archiwalny” 2013, nr 22, s. 27-50.
} 
metrykalnych bądź akt stanu cywilnego dotyczą konkretnych osób, które w zdecydowanej większości nie były dotąd obiektem badań historycznych, a wiedza o nich przeminęła dziesiątki lat temu, szczególnie wraz z przerwaniem ciągłości etnicznej w 1945 roku. Analiza tych danych pozwala po części opisać zwyczaje związane z zawieraniem związku małżeńskiego, ale też zarysować obraz społeczeństwa - jego strukturę, a także mobilność społeczną i przestrzenną. Badania takie dają też możliwość przeprowadzenia analizy porównawczej charakterystyki demograficznej Pomorza Zachodniego z regionami zamieszkanymi w większości przez ludność polską.

Małżeństwa cywilne zostały wprowadzone w Niemczech w 1873 roku w ramach tak zwanych praw majowych ${ }^{5}$. Był to jeden z elementów polityki Kulturkampfu zapoczątkowanej przez kanclerza Rzeszy Ottona von Bismarcka. Kolejnym etapem laicyzacji instytucji małżeństwa stała się ustawa pruska z marca 1874 roku wprowadzająca rejestrację związków małżeńskich przed urzędnikiem państwowym. W 1875 roku Reichstag uchwalił podobną ustawę dla wszystkich krajów Rzeszy ${ }^{6}$. Ustawy te stały się podstawą organizacji sieci urzędów stanu cywilnego prowadzących ewidencję małżeństw, urodzeń i zgonów. Państwo odbierało w ten sposób Kościołowi przywilej wyłączności w rejestracji ruchu naturalnego ${ }^{7}$. Nowe prawo wprowadziło obowiązek zawierania małżeństw cywilnych, gdyż jedynie takie nabierały skutków prawnych. Pastorzy oraz księża udzielać mogli ślubów kościelnych jedynie po okazaniu zaświadczenia o zawarciu związku cywilnego, a nieprzestrzeganie tego prawa skutkowało karą grzywny lub karą trzech miesięcy pozbawienia wolności ${ }^{8}$.

Mimo niewątpliwych kosztów uruchomienia nowej machiny urzędniczej, władze państwowe dostrzegały zalety prowadzenia rejestracji urodzeń, małżeństw i zgonów. Pozyskane w ten sposób dane statystyczne stanowiły nieocenione źródło informacji na temat poszczególnych obywateli państwa niemieckiego. Umożliwiały też prowadzenie ogólnej obserwacji kondycji demograficznej i społecznej różnych regionów państwa. Zbiorcze dane syntetyczne publikowało założone w 1805 roku w Berlinie Pruskie Biuro Statystyczne9.

\footnotetext{
${ }^{5}$ Zbigniew Klotzke, Ludność obwodu urzędu stanu cywilnego Luzino w latach 1874-1918, PDP 12, 1981, s. 68.

${ }^{6}$ Maciej Szukała, Powstanie, organizacja i działalność urzędów stanu cywilnego w okręgach wiejskich na Pomorzu w latach 1874-1945, [w:] II międzynarodowa konferencja naukowa: Dzieje wsi pomorskiej, red. Radosław Gaziński, Andrzej Chudziński, Dygowo-Szczecin 2003, s. 51.

${ }^{7}$ Od 1794 roku prowadzoną przez duchowieństwo rejestrację wyznaniową wykorzystywano również w celach świeckich. Zgodnie z przepisami duplikaty ksiąg były przekazywane instytucjom państwowym.

${ }^{8}$ Tamże, s. 52.

${ }^{9}$ Por. Tadeusz Ładogórski, Złudzenia pruskiej statystyki ludności pierwszej połowy XIX w. i próby jej korekty na Śląsku, PDP 3, 1970, s. 6.
} 
Księgi urzędów stanu cywilnego prowadzone były przez urzędników państwowych i stanowiły dokument prawny. Poprawność ich była kontrolowana przez urzędy centralne, które publikowały krajowe opracowania statystyczne ${ }^{10}$. W Prusach urzędowa rejestracja związków małżeńskich została wprowadzona najwcześniej spośród krajów Rzeszy i dlatego trudno dostrzec realne przesłanki podważające wiarygodność badanej dokumentacji. Dodać należy, że za wszelkie zaniedbania i nieprawidłowości tak dla urzędników, jak i wobec zwykłych obywateli przewidziane były sankcje karne ${ }^{11}$.

Jednym z elementów działań modernizacyjnych było ustanowienie obwodów urzędów stanu cywilnego (Standesamtbezirk), które nie zawsze pokrywały się z dotychczasowym podziałem administracyjnym. Niekiedy w skład jednego obwodu wchodziło kilka gmin, w innym wypadku jedną gminę dzielono na kilka obwodów. Kryterium podziału była liczba mieszkańców przypadająca na jeden urząd $^{12}$. Zależnie od potrzeb zmieniał się niekiedy skład poszczególnych obwodów. Tak było również w przypadku USC Gumieńce. W całym badanym okresie, czyli od momentu wyodrębnienia obwodu urzędu stanu cywilnego w Gumieńcach, do roku 1906 pod miejscowy USC podlegały 3 sąsiednie gminy (Landgemeinden): Gumieńce, Pomorzany (Pommerensdorf), Mierzyn (Möhringen) oraz cztery tak zwane obszary dworskie (Gutsbezirke): Ostoja (Schadeleben), majątek Gumieńce (Scheune Gut), Świerczewo (Schwarzow) i Przylep (Prilipp). Podlegająca początkowo pod urząd w Gumieńcach miejscowość Stobno (Stöven) została w 1900 roku wyłączona z obwodu, ponieważ utworzono tam nowy USC. W tym samym czasie - od roku 1901 - w skład USC Gumieńce weszła miejscowość Krzekowo (Kreckow) oraz obszar dworski Eckersberg (majątek arkoński), które wcześniej podlegały pod urząd w Niemierzynie (Nemitz).

\footnotetext{
${ }^{10}$ Materiał był bowiem przekazywany bezpośrednio do założonego w 1805 roku w Berlinie Pruskiego Biura Statystycznego. Por. tamże.

${ }^{11}$ Dariusz Szudra, Bilanse migracyjne pruskiej prowincji Pomorze w latach 1875-1890, PDP 25, 2004, s. 82. Więcej zastrzeżeń można spotkać w literaturze wobec wiarygodności danych zawartych w księgach metrykalnych parafii, ale także na przykład w odniesieniu do niemieckich spisów ludności. Por. Bronisław Wojtun, Ocena jakości pruskiej statystyki ludnościowej przy użyciu równań bilansujacych, PDP 9, 1976, a także T. Ładogórski, Złudzenia pruskiej statystyki ludności [9], s. 3.

${ }^{12}$ Z. Klotzke, Ludność obwodu [5], s. 69. W prowincji pomorskiej powstało 652 urzędów stanu cywilnego: $304 \mathrm{w}$ rejencji szczecińskiej, $253 \mathrm{w}$ rejencji koszalińskiej i $94 \mathrm{w}$ rejencji stralsundzkiej. Po zlikwidowaniu niektórych urzędów ich liczba w 1877 roku osiągnęła 609 i zmieniała się w dalszym ciągu w miarę potrzeby. W powiecie Randow ustanowiono początkowo 34 urzędy stanu cywilnego. 1 urząd powołano również w miejskim powiecie Szczecin. Por. M. Szukała, Powstanie, organizacja i działalność [6], s. 51.
} 
Wtóropisy (tzw. Nebenregister) akt ślubów USC w Gumieńcach przechowywane są obecnie w Archiwum Państwowym w Szczecinie ${ }^{13}$. Zawierane małżeństwa były spisywane każdego roku w nowej księdze, a wraz z zakończeniem roku urzędnik zamykał księgę stosowną adnotacją z podaniem liczby zawartych małżeństw oraz datą. Podstawą dokumentu był sformalizowany formularz $\mathrm{w}$ języku niemieckim, wypełniany następnie przez urzędnika stanu cywilnego pismem neogotyckim (na ogół z wyjątkiem nazwisk i nazw miejscowości, które pisane były pismem renesansowym). Na początku nie zapisywano, z jakich dokumentów pochodzą dane uzyskane od nupturientów i świadków małżeństwa. Można wnioskować, że informacje były zatem uzyskiwane w wyniku przekazu ustnego. Dopiero od 1882 roku sporadycznie, a od 1891 roku regularnie poświadczano dane osobowe stosownym dokumentem, najczęściej metryką chrztu, świadectwem wojskowym lub świadectwem zatrudnienia bądź relacją jednego ze świadków.

Podstawą aktu stanu cywilnego był sformalizowany formularz, w którym od 1875 roku umieszczano następujące dane:

1. Numer aktu, miejscowośćc ${ }^{14}$, data ślubu (dzień, miesiąc, rok) ${ }^{15}$.

2. Dane dotyczące nupturienta: imiona, nazwisko, zawód, wyznanie, datę urodzenia $^{16}$, miejsce urodzenia i miejsce zamieszkania, sposób ustalenia tożsamości.

3. Dane dotyczące nupturientki: imiona, nazwisko, zawód, stan cywilny, ewentualnie imię i nazwisko oraz zawód poprzedniego męża, wyznanie, datę urodzenia ${ }^{17}$, miejsce urodzenia, miejsce zamieszkania, sposób ustalenia tożsamości.

4. Dane dotyczące rodziców nupturientów: imiona, nazwiska, zawody (tylko ojców), nazwisko rodowe matki, miejsca zamieszkania lub śmierci, informacja, czy żyli, gdy zawierano małżeństwo.

5. Dane dotyczące świadków małżeństwa: imiona, nazwiska, zawody, wiek, miejsca zamieszkania, sposób ustalenia tożsamości.

6. Podpis (nazwisko) urzędnika stanu cywilnego.

${ }^{13}$ Archiwum Państwowe w Szczecinie, Urząd Stanu Cywilnego Szczecin-Gumieńce, sygn. 18-45, 76, 81, 84. Wszystkie następne nawiązania do akt stanu cywilnego USC Gumieńce odnoszą się do wymienionej wyżej dokumentacji.

${ }^{14}$ Do 27 czerwca 1890 roku Gumieńce, od 7 lipca 1890 roku Szczecin.

${ }^{15} \mathrm{~W} 1875$ roku zapisywano ponadto dokładną godzinę ślubu, jednak już w kolejnych latach zaniechano tej praktyki.

${ }^{16} \mathrm{~W} 1875$ roku zamiast daty urodzenia podawano wiek nupturienta oraz nupturientki.

${ }^{17}$ Archiwum Państwowe w Szczecinie, Urząd Stanu Cywilnego Szczecin-Gumieńce, sygn. $18-45,76,81,84$. 
7. Dane zapisywane na marginesach: ewentualne powtórne małżeństwa rodziców, ewentualnie informacje o rozwodzie, sprostowania błędów ${ }^{18}$.

Dokumentacja stanu cywilnego z badanego okresu zachowała się w bardzo dobrym stanie. Są to oprawione księgi formatu A2. Pomimo że dość często zmieniali się urzędnicy, pismo jest na ogół staranne i w zdecydowanej większości czytelne. Jedynym mankamentem są częste błędy typograficzne oraz brak konsekwencji w jednolitym zapisywaniu imion, nazwisk i nazw miejscowości.

W badaniach posłużono się dotychczas publikowanymi w Polsce pracami naukowymi w dziedzinie demografii historycznej. Pierwsze opracowania na ten temat publikowano na początku lat siedemdziesiątych w czasopiśmie „Przeszłość Demograficzna Polski”. Był to w Polsce początek zainteresowania tymi zagadnieniami ${ }^{19}$. Pojawiły się pierwsze prace teoretyczne i metodologiczne, publikowano również wyniki studiów regionalnych nad demografią poszczególnych miejscowości. Źródłem tego typu badań były na początku przede wszystkim sporządzane przez duchownych parafialne księgi metrykalne. Jednymi z pierwszych demografów historycznych, którzy zajęli się analizą akt ślubów byli: Barbara Nowakowska, Emilia Brodnicka i Edmund Piasecki ${ }^{20}$. Pomocne w trakcie pracy badawczej były przede wszystkim rozwiązania metodologiczne zaproponowane przez Zbigniewa Klotzke, Sabinę Rejman, Elżbietę Kościk, Stefanię Glikman-Kowalską i Hannę Kurowską ${ }^{21}$. W badaniach korzystano też z opracowań dotyczących samej metodologii badań z dziedziny demografii historycznej ${ }^{22}$.

${ }^{18} \mathrm{Na}$ nieco innym formularzu prowadzone były karty wysyłane od 1875 roku co kwartał przez urzędy stanu cywilnego do Pruskiego Biura Statystycznego. Zawierały informacje wyłącznie na temat nupturientów, w tym poza danymi zawartymi w formularzu aktu stanu cywilnego umieszczano między innymi ewentualny stopień pokrewieństwa, umiejętność zapisu własnego nazwiska oraz, co najmniej od 1903 roku, pozycję w zawodzie. Zob. Preussische Statistik, 1876, Bd. 45, s. 14; Preussische Statistik, 1903, Bd. 190, s. 14.

${ }^{19} \mathrm{Nie}$ bez wpływu na te zainteresowania pozostawała literatura obcojęzyczna, na przykład prace Petera Lasletta. Zob. An Introduction to English Historical Demography, red. Edward A. Wrigely, London 1966.

${ }^{20}$ Barbara Nowakowska, Przyczynek do zagadnień struktury demograficznej guberni płockiej w 1890 r., PDP 1, 1967; Emilia Brodnicka, Ludność parafii Wieluń nad Notecia w drugiej połowie XVIII w. (rekonstrukcja rodzin), PDP 3, 1970; Edmund Piasecki, Ludność parafii Bejskiej w świetle ksiag metrykalnych z XVIII-XX w. Studium demograficzne, Warszawa 1990.

${ }^{21}$ Zob. Z. Klotzke, Ludność obwodu [5]; Sabina Rejman, Ludność podmiejska Rzeszowa w latach 1784-1880. Studium demograficzno-historyczne, Rzeszów 2006; Elżbieta Kościk, Przemiany w strukturze społeczno-zawodowej i demograficznej ludności Opola w drugiej połowie XIX wieku na podstawie ksiag parafialnych i akt USC, Wrocław 1993; Stefania Kowalska-Glikman, Ruchliwość społeczna i zawodowa mieszkańców Warszawy w latach 1845-1861, Warszawa-Kraków 1971; Hanna Kurowska, Struktura demograficzna gubińskiej rodziny w pierwszej połowie XIX wieku, [w:] Rodzina i gospodarstwo domowe na ziemiach polskich w XV-XX wieku, red. Cezary Kuklo, Warszawa 2008.

${ }^{22}$ Między innymi: Irena Gieysztorowa, Wstęp do demografii staropolskiej, Warszawa 1976; Cezary Kuklo, Demografia Rzeczpospolitej, Warszawa 2009. 


\section{Charakterystyka obwodu USC Gumieńce}

W opisywanym okresie Pomorze Zachodnie weszło w stadium zaawansowanej transformacji demograficznej, odznaczającej się zahamowaniem i stabilizacją współczynnika zgonów oraz spadkiem rodności ${ }^{23}$. Intensywne przemiany demograficzne zbiegły się w czasie z kryzysem rolniczym, który od końca lat siedemdziesiątych XIX wieku wpływał na wyludnianie pomorskiej wsi ${ }^{24}$. Brak pracy, niskie dochody, rosnące ubóstwo i brak perspektyw na przyszłość wymuszały na ludności rolniczej poszukiwanie nowych celów migracji. Jednym z popularnych kierunków okazały się Stany Zjednoczone, dokąd w pierwszej połowie lat osiemdziesiątych XIX wieku wyemigrowało prawie 100 tysięcy mieszkańców Pomorza Zachodniego ${ }^{25}$. Pozostali próbowali szukać pracy bliżej - w innych regionach Rzeszy Niemieckiej (głównie w pobliskiej Brandenburgii) lub w prężnie rozwijającym się Szczecinie ${ }^{26}$. Stolica Pomorza Zachodniego nie odczuła ani kryzysu w rolnictwie, ani intensyfikacji zjawiska emigracji zamorskiej. Liczba mieszkańców miasta wzrastała w szybkim tempie. Ludność napływowa znajdowała zatrudnienie w przemyśle i rzemiośle, a miejsce zamieszkania - na ogół w osiedlach podmiejskich, później także w centrum miasta ${ }^{27}$.

Dwa kolejne procesy zadecydowały o charakterze przemian demograficznych, gospodarczych i społecznych w Szczecinie i w najbliższej okolicy. Była to likwidacja fortyfikacji miejskich i rozpoczęcie zabudowy terenów pofortecznych,

${ }^{23}$ Kazimierz Wajda, Stosunki ludnościowe na ziemiach pomorskich $w$ latach 1850-1914, [w:] Historia Pomorza, t. IV: (1850-1918), cz. I: Ustrój, gospodarka, społeczeństwo, red. Stanisław Salmonowicz, Toruń 2000, s. 72-73.

${ }^{24}$ B. Wojtun, Ocena jakości pruskiej statystyki ludnościowej [11], s. 33. Import tańszej żywności z Rosji i ze Stanów Zjednoczonych spowodował, że miejscowe produkty traciły rynek zbytu. To z kolei oznaczało pauperyzację drobnych wytwórców, u właścicieli większych gospodarstw wymusiło zaś takie zmiany, jak modernizacja technologiczna i racjonalizacja zatrudnienia. Por. Dariusz Szudra, Tendencje $w$ przemianach demograficznych $w$ pruskiej prowincji Pomorze na tle trendów ogólnoniemieckich w latach 1871-1914, „Przegląd Zachodniopomorski” 2000, z. 4, s. 32.

${ }^{25} \mathrm{~W}$ latach 1883-1888 Stany Zjednoczone stanowiły cel podróży dla 95-98,2\% wysiedleńców z Pomorza Zachodniego. Spośród pozostałych państw wybierano również Kanadę, kraje Ameryki Południowej czy Australię, jednak skala tego zjawiska była nieporównywalnie mniejsza. Największą grupę spośród emigrantów zamorskich stanowili bezrolni robotnicy, zwłaszcza służba folwarczna. Z miast emigrowała ludność zatrudniona w podmiejskich gospodarstwach rolnych. Liczną grupę stanowiła także młodzież pochodząca z małych lub średnich gospodarstw rolnych a także młodzież miejska. Por. Bogusław Drewniak, Emigracja z Pomorza Zachodniego 1816-1914, Poznań 1966, s. 57-66.

${ }^{26}$ Emigrowali głównie ludzie młodzi, zdolni do pracy fizycznej, częściej mężczyźni niż kobiety. Społeczeństwo starzało się, na wsi pomorskiej zaczął pojawiać się problem braku siły roboczej.

${ }^{27}$ Osiedlająca się w rejonie aglomeracji szczecińskiej ludność wiejska znajdowała zatrudnienie w przemyśle, gdzie w latach osiemdziesiątych XIX wieku mogła liczyć na zarobki nawet dwukrotnie wyższe niż w rolnictwie. Por. Edward Włodarczyk, Wielki przemyst Szczecina w latach 1850-1914, Warszawa-Poznań 1982, s. 49. 
a także oddziaływanie na sąsiednie miejscowości, co skutkowało między innymi włączeniem w obręb granic administracyjnych Szczecina Grabowa (Grabow), Drzetowa (Bredow) i Niemierzyna. Od tego momentu datuje się początek dynamicznego rozwoju budownictwa mieszkalnego, przemysłowego i komunalnego w mieście ${ }^{28}$. Jak stwierdził Tadeusz Białecki: „Największy rozmach inwestycji miejskich przypadł na 1. 1873-1914. (...) W zasadzie do 1910 r. zabudowano i uporządkowano wszystkie tereny poforteczne, na których wyrosło nowe miasto, obecne Śródmieście Szczecina"29. Likwidacja fortyfikacji pozwoliła w większym stopniu związać miasto z okolicznymi dzielnicami przemysłowymi. Na terenach zajmowanych dotychczas przez wojsko można było budować nowe zakłady przemysłowe i rozszerzać osiedla robotnicze dla napływającej do Szczecina ludności wiejskiej.

Największą miejscowością wchodzącą w skład USC Gumieńce były Pomorzany $^{30}$. W XIX wieku nastąpił gwałtowny rozwój Pomorzan, tradycyjna rolnicza wieś zaczęła się bowiem przekształcać w zurbanizowane i zindustrializowane przedmieście Szczecina. Ponadto w latach dwudziestych XIX wieku wzdłuż ówczesnej Apfelallee (obecna aleja Powstańców Wielkopolskich) powstało nowe osiedle robotnicze, które nazwano Kolonią Pomorzany (Pommerensdorfer Anlage).

W 1871 roku w Pomorzanach mieszkało tylko 1120 osób, w 1895 roku już 2700, a 10 lat później 4100³1. Wzrost liczby ludności następował w wyniku napływu ludności wiejskiej z regionu. Jeszcze w 1871 roku Pomorzany były pod względem zaludnienia 13. miejscowością w powiecie Randow (nie licząc miast, były na 8. miejscu). W 1905 roku zajmowały już w tej klasyfikacji 6. miejsce, ustępując jedynie dwóm miastom - Dąbiu (Altdamm) i Policom (Pölitz) oraz trzem wsiom - Żelechowej (Züllchow), Stołczynowi (Stolzenhagen) i Podjuchom (Podejuch). Jednocześnie Pomorzany wyprzedzały pod względem liczby ludności dwa miasta

\footnotetext{
${ }^{28}$ Tadeusz Białecki, Historia Szczecina, Wrocław-Warszawa-Kraków 1992, s. 209.

${ }^{29}$ Tamże. Warto wspomnieć, że w tym okresie swój urząd sprawowali najbardziej zasłużeni spośród nadburmistrzów Szczecina - Hermann Haken i następnie Friedrich Ackermann.

${ }^{30}$ Współcześnie Pomorzany są dzielnicą Szczecina.

${ }^{31}$ Die Gemeinden und Gutsbezirke des Preußischen Staates und ihre Bevölkerung. Nach dem Urmaterialien der allgemeinen Volkszählung vom 1. Dezember 1871, Bd. 3: Provinz Pommern, bearb. vom Königlichen Statistischen Bureau, Berlin 1874, s. 26-33; Gemeindelexikon für das Königreich Preußen. Auf Grund der Materialien der Volkszählung vom 1. Dezember 1885 und anderer amtlicher Quellen, Bd. 4: Provinz Pommern, bearb. vom Königlichen Statistischen Bureau, Berlin 1888, s. 29-37; Gemeindelexikon für das Königreich Preußen. Auf Grund der Materialien der Volkszählung vom 2. Dezember 1895 und anderer amtlicher Quellen, Bd. 4: Provinz Pommern, bearb. vom Königlichen Statistischen Bureau, Berlin 1898, s. 30-37; Gemeindelexikon für das Königreich Preußen. Auf Grund der Materialien der Volkszählung vom 1. Dezember 1905 und anderer amtlicher Quellen, Bd. 4: Provinz Pommern, bearb. vom Königlichen Statistischen Bureau, Berlin 1908, s. 118-125.
} 
powiatu Randow - Gartz an Oder i Penkun. O rozwoju miejscowości świadczy też ponad dwukrotny wzrost liczby budynków mieszkalnych w badanym okresie.

Wraz z rozwojem gospodarczym Szczecina w Pomorzanach zaczęły powstawać liczne zakłady przemysłowe. Już w 1864 roku było ich 48: między innymi 4 wiatraki zbożowe, 1 młyn parowy zbożowy połączony z olejarnią, 2 duże cegielnie, 2 browary ${ }^{32}$. Od 1857 roku działała jako spółka akcyjna fabryka chemiczna Pommerensdorf. Było to jedno z największych przedsiębiorstw w całych Pru$\operatorname{sach}^{33}$. Fabryka była też cały czas rozbudowywana, a zatrudnienie rosło. W 1873 roku pracowało tam 550 osób, w 1904 roku już 825 osób $^{34}$. Produkowano tam sodę oczyszczoną, szuwaks, mączkę kostną, sól gorzką, boraks, chlorek wapnia, sól glauberską, kwas saletrowy, kwas siarkowy, kwas cynkowy, wapno palone ${ }^{35}$.

W latach siedemdziesiątych i osiemdziesiątych XIX wieku powstawało wiele nowych zakładów przemysłowych: Szczecińska Fabryka Pieców, Pomorska Fabryka Mydła i Chemikaliów, Fabryka Tłuszczu Wagonowego braci Leduc, Szczecińska Fabryka Szamotu i Szamotowych Retort Gazowych SA, fabryka drewna użytkowego i skrzynek Brunnera i Wella, gorzelnia parowa Kielmanna, odlewnia żelaza Schwartza, tartak Müllera (na wyspie Krainka), fabryka margaryny, fabryka maszyn rolniczych, młynarskich, ogrodniczych, wytwórnia krzyży nagrobnych, wytwórnie drożdży prasowanych, spirytusu, likieru, rumu i octu ${ }^{36}$. Industrializacja Pomorzan nie stała na przeszkodzie rozwojowi rzemiosła. W 1875 roku pracowało tam między innymi 6 stolarzy, 6 bednarzy, 6 szewców, 2 kołodziejów, garncarz, kowal i cieśla ${ }^{37}$.

W Pomorzanach wybudowano także duży zakład gazowniczy (gazu używano głównie do oświetlania ulic miasta) oraz publiczny szpital miejski. Wybudowana w 1879 roku placówka miała odrębne pawilony dla kobiet i mężczyzn na około 250 łóżek $^{38}$. W tym okresie była to jedna z najnowocześniejszych klinik w Niemczech.

${ }^{32}$ Tadeusz Białecki, Lucyna Turek-Kwiatkowska, Szczecin stary i nowy, Szczecin 1991, s. 204.

${ }^{33}$ Tamże.

${ }^{34} \mathrm{~W} 1882$ roku - 600, w 1894 roku - 750 osób. Por. Edward Włodarczyk, Wielkomiejski rozwój Szczecina w latach 1871-1918, [w:] Dzieje Szczecina 1806-1945, red. Bogdan Wachowiak, Szczecin 1994, t. III, s. 395.

${ }^{35}$ T. Białecki, L. Turek-Kwiatkowska, Szczecin stary [32], s. 204. W 1890 roku w fabryce produkowano łącznie 50 tysięcy ton różnych wyrobów o wartości 4,2 mln marek. Zob. E. Włodarczyk, Wielkomiejski [34], s. 359.

${ }^{36}$ Por. T. Białecki, L. Turek-Kwiatkowska, Szczecin stary [32], s. 204; Marek Łuczak, Szczecin-Pomorzany-Pommerensdorf, Szczecin 2010, s. 33, 108, 114.

${ }^{37}$ Tamże, s. 32-33.

${ }^{38}$ T. Białecki, L. Turek-Kwiatkowka, Szczecin stary [32], s. 205. Pod koniec wieku powstała w szpitalu również nowoczesna sala operacyjna z oświetleniem gazowym, a następnie elektrycznym. Zainstalowano też aparat rentgenowski. Zob. tamże. 
Intensywne uprzemysłowienie Pomorzan wymusiło usprawnienie miejscowej sieci komunikacyjnej. W latach dziewięćdziesiątych XIX wieku wybudowany został dworzec Pomorzany wraz z bocznicami, peronami pasażerskimi oraz peronami do wyładunku towarów ${ }^{39}$. Powstały też dwie stacje kolei wąskotorowej oraz stacja dorożek, które (zanim wprowadzono tramwaje) stały się głównym środkiem transportu dla dojeżdżających do pracy urzędników i robotników.

Pomorzany były w drugiej połowie XIX wieku przemysłowym i robotniczym zapleczem Szczecina, głównie za sprawą ludności napływowej. Pośród autochtonów przez długi czas dominowali wszakże rolnicy. W 1864 roku w Pomorzanach istniało 12 pełnorolnych gospodarstw chłopskich, 2 duże posiadłości i 3 małe własności zagrodników, 7 starych parcel należących do budników, 12 nowych zabudowań na gruntach wiejskich i 3 gospodarstwa na parcelach łąkowych ${ }^{40}$. Narastająca industrializacja i urbanizacja wpłynęła na postępujące stopniowo zmiany w strukturze społecznej i zawodowej, a także na tendencje urbanistyczne i mieszkaniowe przemysłowych przedmieść Szczecina ${ }^{41}$. Jak pisał Edward Włodarczyk: „Na osiedla z nowym zakładem następowała inwazja nowych warstw społecznych, na rzecz których traciła całkowicie znaczenie dotychczasowa ludność, trudniąca się rzemiosłem lub rolnictwem"^2. W Pomorzanach zaczęły powstawać większe i mniejsze zakłady przemysłowe, których właścicielami byli szczecińscy kapitaliści, siłę roboczą stanowili zaś mieszkańcy przedmieść oprócz imigrantów także miejscowi rzemieślnicy, rolnicy, robotnicy dniówkowi. Podczas gdy ludność Pomorzan liczyła w 1875 roku 1800 mieszkańców, już dwa lata wcześniej zatrudnienie w fabryce Pommerensdorf wyniosło 550 osób. To ilustruje, jak znaczący odsetek mieszkańców zatrudniony był w wielkich zakładach przemysłowych.

W rezultacie przemian gospodarczych i migracji ludności zaczął się zmieniać także architektoniczny obraz Pomorzan. Dominować zaczęło budownictwo czynszowe i koszarowe ${ }^{43}$. Mimo że budowano coraz więcej domów, już w latach dziewięćdziesiątych XIX wieku pojawiły się problemy mieszkaniowe. Wiele osób żyło w bardzo trudnych warunkach, a mieszkania nie spełniały podstawowych wymogów. W Pomorzanach aż 85\% stanowiły mieszkania małe (jedno- lub dwupokojowe, gdzie na ogół tylko w jednym pokoju znajdował się piec, często też

${ }^{39}$ M. Łuczak, Szczecin - Pomorzany [36], s. 154.

${ }^{40}$ T. Białecki, L. Turek-Kwiatkowska, Szczecin stary [32], s. 213.

${ }^{41} \mathrm{O}$ demograficznych następstwach procesu urbanizacji w obrębie aglomeracji szczecińskiej:

D.K. Chojecki, Od społeczeństwa tradycyjnego [1], s. 52-62.

${ }^{42}$ E. Włodarczyk, Wielkomiejski [34], s. 310.

${ }^{43}$ Tamże, s. 290-291, 310. 
brakowało kuchni) - to najwyższy odsetek w strefie okołomiejskiej Szczecina ${ }^{44}$. Również w Gumieńcach w omawianym okresie wznoszono przede wszystkim małe domki jednorodzinne o niskim standardzie technicznym, które przeznaczone były dla robotników i innych pracowników o niższych dochodach ${ }^{45}$.

Gospodarcze i społeczne powiązania Pomorzan ze Szczecinem nabrały nowego wymiaru, gdy w 1822 roku powstało w najbliższym sąsiedztwie właściwej wsi Pomorzany na gruntach należących do miasta nowe osiedle robotnicze - tak zwana Kolonia Pomorzany. Korzystne położenie wpłynęło na szybki wzrost liczby mieszkańców, którzy osiedlali się w wielorodzinnych, czynszowych domach robotniczych. Na terenie Kolonii znajdowała się większość zakładów przemysłowych związanych funkcjonalnie z miastem - między innymi fabryka chemiczna. Mimo to władze wsi opowiadały się za odłączeniem Kolonii, gdyż nie były w stanie ponosić ciężarów komunalnych ${ }^{46}$. W 1865 roku osiedle ostatecznie zostało włączone w granice administracyjne Szczecina. Na terenie włączonym do miasta znajdowały się 63 posesje, 68 domów mieszkalnych, 48 budynków magazynowych i fabrycznych, 211 stajni, stodół i szop. Ponadto 5 wiatraków, 1 młyn parowy, 2 młyny olejowe, 2 cegielnie, browar, fabryka mydła, gazownia miejska. Fabryka Produktów Chemicznych - w wyniku starań władz powiatu - ostatecznie pozostała w granicach wsi. Przyłączony obszar zamieszkiwało wówczas 1566 osób (330 rodzin) ${ }^{47}$. Z Kolonii utworzono przedmieście Szczecina, a później 24. obwód miejski. Parafia ewangelicka zaś nadal należała do wsi Pomorzany. W 1872 roku do Kolonii dołączono teren zwany Galgwiese z 24 budynkami mieszkalnymi ${ }^{48}$.

Gumieńce były wsią położoną na zachód od Szczecina i północny zachód od Pomorzan. Tutaj właśnie mieściła się siedziba okręgu urzędu stanu cywilnego. W przeciwieństwie do Pomorzan, liczba mieszkańców Gumieniec utrzymywała

${ }^{44}$ Tamże, s. 456-457. Oprócz niekorzystnej sytuacji mieszkaniowej mieszkańcy przedmieść i osiedli przemysłowych mieli także inne problemy - wysoki był między innymi poziom przestępczości, alkoholizmu i prostytucji. Niski poziom higieniczno-sanitarny wpływał na wysoką śmiertelność w wyniku chorób wenerycznych, gruźlicy i tyfusu. Dopiero pod koniec XIX wieku dzień pracy został skrócony z 14-16 do 12 godzin, a niedzielę ustanowiono dniem wolnym od pracy. Znane były także przypadki wykorzystywania pracy dzieci. Por. tamże, s. 419, 465, 469, 473, 475.

${ }^{45}$ Mieszkania o wyższym standardzie budowano przede wszystkim w nowych ekskluzywnych dzielnicach: na Pogodnie i w Łęknie. Por. T. Białecki, Historia [28], s. 211.

${ }^{46}$ T. Białecki, L. Turek-Kwiatkowska, Szczecin stary [32], s. 203.

${ }^{47}$ Bogdana Kozińska, Rozwój przestrzenny Szczecina, od początku XIX wieku do II wojny światowej, Szczecin 2002, s. 120. Część mieszkańców trudniła się rolnictwem (s. 121). Część mieszkańców Kolonii zajmowała się rzemiosłem. W 1864 roku był tu 1 krawiec, 2 szewców, 2 bednarzy, 4 garncarzy. W granicach przyłączonego terenu mieściły się też: 1 sklep tekstylny, 2 pasmanteryjne, 5 spożywczych i 7 karczm. Reszta ludności zatrudniona była w zakładach przemysłowych i rzemieślniczych Szczecina i często pracowała w charakterze robotników dniówkowych bądź pracowników dorywczych. Zob. tamże.

${ }^{48}$ Tamże, s. 122. 
się na podobnym poziomie w całym badanym okresie (około 800 osób) ${ }^{49}$. Jedynie w latach siedemdziesiątych XIX wieku zanotowano wzrost liczby ludności. W 1871 roku mieszkało w Gumieńcach tylko 574 osób.

W 1862 roku znajdowało się w Gumieńcach, łącznie z folwarkami Ostoja i Słowieńsko, 48 domów i 64 budynki gospodarcze, a zamieszkiwało je 770 osób ${ }^{50}$. Miejscowość ta była też zdecydowanie mniej uprzemysłowiona. $Z$ zakładów przemysłowych wymienić należy cegielnię, w której produkowano 200 tysięcy cegieł rocznie, oraz dwie mniejsze cegielnie i jedną w Słowieńsku (Wendorf) ${ }^{51}$. Zakłady te wykorzystywały lokalne pokłady gliny i margla. W 1884 roku powstała również na Gumieńcach cukrownia (Zuckerfabrik Scheune GmbH), która stała się jednym $\mathrm{z}$ największych przedsiębiorstw $\mathrm{w}$ regionie i jednocześnie właściwie jedynym dużym zakładem przemysłowym w zachodniej części aglomeracji szczecińskiej. Cukrownia przerabiała zwykle 2 tysiące kwintali buraków w ciągu doby, a w czasie sezonu nawet 10 tysięcy $^{52}$. Kapitał zakładowy przedsiębiorstwa wynosił 760 tysięcy marek ${ }^{53}$.

Część mieszkańców posiadała drobne działki i zajmowała się uprawą roli. Dużą grupę stanowili także bezrolni komornicy, którzy pracowali w Szczecinie. Niewielu było natomiast w Gumieńcach rzemieślników. Jeszcze w 1865 roku pracował tu 1 krawiec, 1 szewc i 2 kowali. Był sklep spożywczy, karczma, przytułek dla ubogich i dwuklasowa szkoła z jednym nauczycielem ${ }^{54}$. W granicach wsi znajdowały się dwa folwarki: majątek Gumieńce i Ostoja (Gutshaus Schadeleben) ${ }^{55}$.

Na rozwój Gumieniec wpłynęła przede wszystkim budowa cukrowni. Pod koniec wieku rozpoczęto także budowę Cmentarza Centralnego. Był to największy tego typu obiekt $w$ regionie i jeden $z$ największych w Europie. $Z$ tego powodu wprowadzono linię autobusową prowadzącą ze Śródmieścia Szczecina do folwarku Słowieńsko ${ }^{56}$. Z kolei mały dworzec kolejowy Scheune stał się ważnym węzłem kolejowym, gdy w 1899 roku otwarto prowadzącą przez Gumieńce linię kolejową Pasewalk-Szczecin Główny oraz linię do Nowego Warpna (Neuwarp) ${ }^{57}$. Choć zatem przemysł nie rozwinął się w Gumieńcach tak bardzo jak

${ }^{49}$ Die Gemeinden [31], s. 26-33; Gemeindelexikon [...] vom 1. Dezember 1885 [31], s. 29-37; Gemeindelexikon [...] vom 2. Dezember 1895 [31], s. 30-37; Gemeindelexikon [...] vom 1. Dezember 1905 [31] s. 118-125.

${ }^{50}$ Marek Łuczak, Szczecin-Gumieńce - Scheune, Szczecin 2006, s. 16.

${ }^{51}$ Tamże.

${ }^{52}$ Tamże, s. 36.

${ }^{53}$ Tamże.

${ }^{54}$ T. Białecki, L. Turek-Kwiatkowska, Szczecin stary [32], s. 113.

${ }_{55}^{55}$ M. Łuczak, Szczecin-Gumieńce [50], s. 32-34.

${ }^{56}$ Tamże, s. 16.

${ }^{57}$ Tamże. 
w Pomorzanach, miejscowość ta również skorzystała z sieci powiązań ze Szczecinem i ogólnej rozwojowej koniunktury aglomeracji szczecińskiej.

Mierzyn znajdował się na zachód od Gumieniec i nie sąsiadował bezpośrednio ze Szczecinem ${ }^{58}$. W badanym okresie nastąpił nieznaczny wzrost liczby ludności w Mierzynie. W 1871 roku mieszkały tam 734 osoby, w 1905 roku - już 800 osób $^{59}$. Była to typowa wieś. Powierzchnia Mierzyna była przeszło dwa razy większa niż Pomorzan i Gumieniec razem wziętych, z kolei liczba ludności była znacznie niższa. Świadczy to o niewielkim zagęszczeniu ludności w tej miejscowości ${ }^{60}$.

Tabela 1. Liczba zamieszkanych domów i liczba mieszkańców

w poszczególnych miejscowościach obwodu USC Gumieńce w latach 1871-1905

\begin{tabular}{|c|c|c|c|c|c|c|c|c|}
\hline \multirow{2}{*}{$\begin{array}{l}\text { Miejscowości obwodu } \\
\text { USC Gumieńce }\end{array}$} & \multicolumn{4}{|c|}{ Liczba zamieszkanych domów } & \multicolumn{4}{|c|}{ Liczba mieszkańców } \\
\hline & 1871 & 1885 & 1895 & 1905 & 1871 & 1885 & 1895 & 1905 \\
\hline \multicolumn{9}{|c|}{ Gminy wiejskie (Landgemeinden) } \\
\hline Pomorzany (Pommerensdorf) & 74 & 87 & 99 & 149 & 1120 & 1879 & 2707 & 4110 \\
\hline Gumieńce (Scheune) & 39 & 50 & 46 & 48 & 574 & 894 & 804 & 827 \\
\hline Mierzyn (Möhringen) & 58 & 65 & 66 & 65 & 734 & 812 & 796 & 800 \\
\hline Stobno (Stöven) & 39 & 39 & 37 & $x$ & 441 & 389 & 387 & $\times$ \\
\hline Krzekowo (Kreckow) & $\times$ & $\times$ & $\times$ & 138 & $\times$ & $\times$ & $\times$ & 1200 \\
\hline \multicolumn{9}{|c|}{ Obszary dworskie (Gutsbezirke) } \\
\hline m. Gumieńce (Scheune Gut) & 4 & 9 & 8 & 10 & 92 & 121 & 116 & 276 \\
\hline Ostoja (Schadeleben) & 3 & 6 & 4 & 5 & 76 & 86 & 80 & 99 \\
\hline Świerczewo (Schwarzow) & 6 & 6 & 6 & 7 & 60 & 47 & 46 & 58 \\
\hline Przylep (Prilipp) & 3 & 4 & 4 & 4 & 51 & 49 & 54 & 56 \\
\hline Eckersberg & $\times$ & $\times$ & $\times$ & 19 & $\times$ & $\times$ & $\times$ & 241 \\
\hline
\end{tabular}

Źródło: Die Gemeinden [31], s. 26-33; Gemeindelexikon [...] vom 1. Dezember 1885 [31], s. 29-37; Gemeindelexikon [...] vom 2. Dezember 1895 [31], s. 30-37; Gemeindelexikon [...] vom 1. Dezember 1905 [31], s. 118-125.

W 1862 roku mieszkało w Mierzynie 12 pełnorolnych chłopów, 1 zagrodnik i 22 komorników ${ }^{61}$. Uprawiano głównie pszenicę, żyto, owies, jęczmień,

${ }^{58}$ Do dzisiaj miejscowość Mierzyn pozostaje poza granicami administracyjnymi Szczecina (choć w 1939 roku znalazł się w granicach tzw. Wielkiego Szczecina).

${ }^{59}$ Die Gemeinden [31], s. 26-33; Gemeindelexikon für die Provinz Pommern, Volkszahlung [31], s. 29-37; Gemeindelexikon für die Provinz Pommern, Auf Grund der Materialien der Volkszahlung vom 2. [31], s. 30-37; Gemeindelexikon für die Provinz Pommern, Auf Grund der Materialien der Volkszahlung vom 1. [31], s. 118-125.

${ }^{60}$ Powierzchnia Mierzyna wynosiła w 1905 roku 867 hektarów, powierzchnia Pomorzan 372 hektary, a powierzchnia Gumieniec - 315 hektarów.

${ }^{61}$ Encyklopedia Szczecina, red. Tadeusz Białecki, Szczecin 1999, t. 1, s. 610. 
ziemniaki i fasolę. Oprócz ludności rolniczej mieszkali tu również rzemieślnicy: 3 krawców, 2 rzeźników, piekarz, 2 szewców, 2 kowali, stelmach i siodlarz ${ }^{62}$. Nie doszło natomiast w XIX wieku do powstania w Mierzynie zakładów przemysłowych ani do napływu ludności z dalszych regionów powiatu. W 1862 roku we wsi znajdowało się 55 domów, 93 obory i stodoły, zabudowania kościelne, 2 sklepy, 2 karczmy oraz młyn wodny o jednym ciągu ${ }^{63}$. Do 1905 roku wybudowano kilka kolejnych domów. Łącznie liczba domów była większa niż w Gumieńcach, a mimo to w całym badanym okresie w Mierzynie mieszkało mniej osób.

Wykres 1. Liczba mieszkańców w obwodzie USC Gumieńce (w latach 1871, 1885, $1895,1905)$ w podziale na Pomorzany i pozostałe miejscowości z wyłączeniem Stobna, Krzekowa i majątku Eckersberg

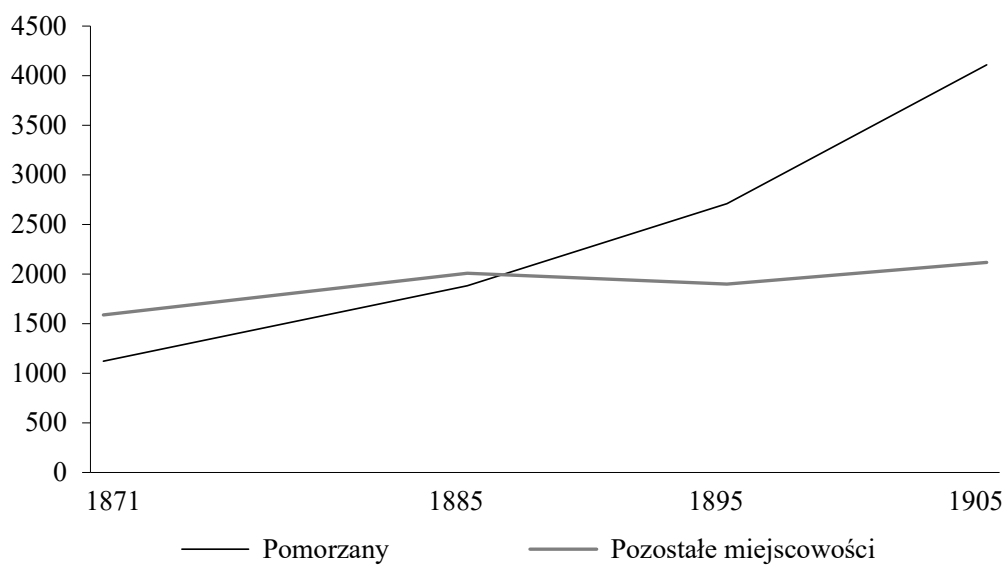

Źródło: Die Gemeinden [31], s. 26-33; Gemeindelexikon [...] vom 1. Dezember 1885 [31], s. 29-37; Gemeindelexikon [...] vom 2. Dezember 1895 [31], s. 30-37; Gemeindelexikon [...] vom 1. Dezember 1905 [31], s. 118-125.

Pomorzany i Mierzyn wchodziły w okręg USC Gumieńce przez cały badany okres. Inaczej było w przypadku położonego na zachód od Szczecina i Gumieniec Stobna. Ta miejscowość została wyłączona z okręgu prawdopodobnie w roku 1900. Wówczas w tej wsi utworzony został nowy urząd stanu cywilnego, powstał tym samym nowy okręg USC. Dane ludnościowe wskazują jednoznacznie, że Stobno nie było w badanym czasie punktem docelowym migracji. Liczba mieszkańców tej wsi zmniejszyła się pod koniec XIX wieku z 441 w 1871 roku do 387

\footnotetext{
62 Tamże.

63 Tamże.
} 
w 1895 roku. Dopiero na początku XX wieku nastąpił wzrost liczby ludności, w 1905 roku mieszkało już w Stobnie 435 osób ${ }^{64}$.

W całym badanym okresie można też zaobserwować w Stobnie nadwyżkę kobiet względem mężczyzn. Najwyższa była ona na początku lat siedemdziesiątych. W 1871 roku na 100 mężczyzn przypadało aż 129 kobiet. O pewnym zacofaniu cywilizacyjnym Stobna świadczy również fakt, że w 1871 roku co dziesiąty mieszkaniec wsi był analfabetą. Dla porównania - czytać ani pisać nie potrafił co dwudziesty piąty mieszkaniec Pomorzan ${ }^{65}$.

Na przełomie wieków do okręgu w Gumieńcach zostało dołączone Krzekowo i posiadłość Eckerberg. Wcześniej podlegały one pod urząd w Niemierzynie ${ }^{66}$. Natomiast w całym badanym okresie do okręgu w Gumieńcach należały jeszcze cztery inne posiadłości ziemskie: Ostoja, posiadłość Gumieńce, Świerczewo i Przylep. Nie są one rozpatrywane indywidualnie ze względu na zbyt małe liczby mieszkańców.

Podsumowując, Pomorzany były najbardziej zindustrializowaną gminą w obwodzie USC Gumieńce, stanowiły właściwe zaplecze przemysłowe Szczecina. Nieliczne zakłady przemysłowe działały również na Gumieńcach, były one ściśle związane ze Szczecinem. Niejako na uboczu aglomeracji znajdował się Mierzyn. Gospodarcze i społeczne różnice pomiędzy tymi trzema miejscowościami sprawiają, że celowe staje się porównanie sytuacji demograficznej oraz przemian w strukturze społecznej poszczególnych miejscowości obwodu urzędu stanu cywilnego Gumieńce.

\section{Roczne liczby malżeństw}

Na liczbę małżeństw zawieranych w ciągu roku mają wpływ wydarzenia polityczne, społeczne oraz ogólna kondycja gospodarcza ${ }^{67}$. W badanym okresie w okręgu USC Gumieńce ludności nie zagrażały już potężne epidemie cholery ${ }^{68}$, państwo niemieckie nie prowadziło też działań wojennych, które mogłyby ograniczyć liczbę zawieranych w danym okresie związków małżeńskich. Na zmiany w rocznej liczbie małżeństw wpływał zatem przede wszystkim ruch naturalny, migracje i sytuacja ekonomiczna ludności.

${ }^{64}$ Die Gemeinden [31], s. 26-33; Gemeindelexikon [...] vom 1. Dezember 1885 [31], s. 29-37; Gemeindelexikon [...] vom 2. Dezember 1895 [31], s. 30-37; Gemeindelexikon [...] vom 1. Dezember 1905 [31], s. 118-125.

${ }^{65}$ Tamże.

${ }^{66}$ W 1900 roku wraz z Grabowem i Drzetowem Niemierzyn został przyłączony do Szczecina.

${ }^{67}$ Por. Waldemar Pasieka, Śluby w parafii opolskiej w latach 1801-1850, PDP 21, 2000, s. 36.

${ }^{68}$ Por. E. Włodarczyk, Wielkomiejski [34], s. 475. 
W latach 1875-1906 (z wyłączeniem roku 1904) zawarto w USC Gumieńce 1357 małżeństw cywilnych. Najwięcej ślubów odnotowano w roku 1903 - 71, najmniej w 1876 - 26. Średnia arytmetyczna to 43,8 rocznie, a odchylenie standardowe od tej średniej 11,5. Pomimo wyraźnych wahań, które są stałym elementem rocznego rozkładu zawieranych małżeństw, w całym badanym okresie następował wzrost liczby małżeństw, co na poniższym wykresie przedstawia przerywana linia trendu.

Wykres 2. Roczne liczby małżeństw w USC Gumieńce w latach 1875-1906 (bez roku 1904)

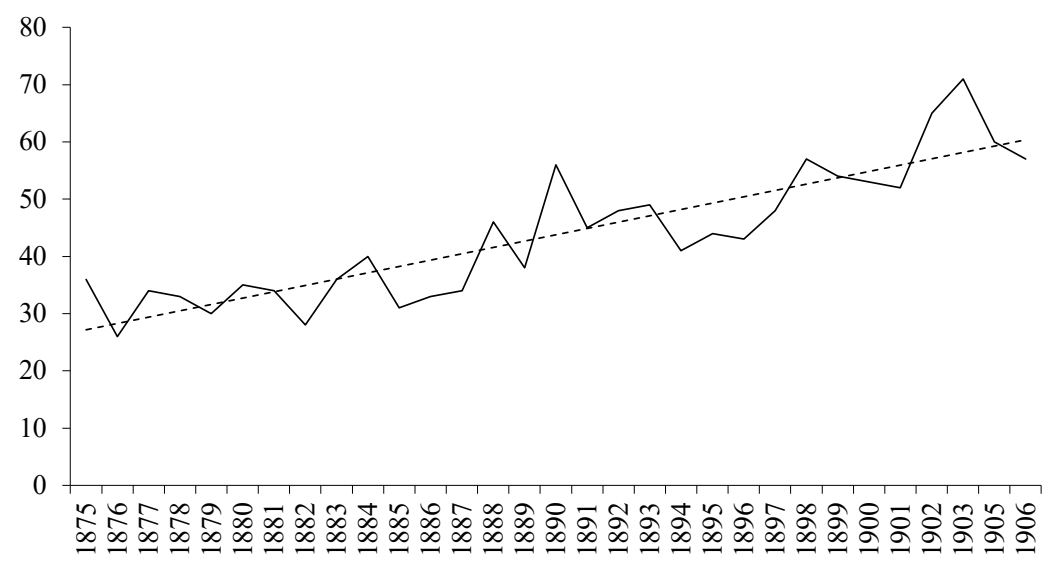

Źródło: obliczenia własne na podstawie: Archiwum Państwowe w Szczecinie, Urząd Stanu Cywilnego Szczecin-Gumieńce, sygn. 18-45, 76, 81, 84.

Pierwszy wyraźny wzrost liczby zarejestrowanych ślubów zaobserwować można w roku 1888 (46 ślubów) i 1890 (56), potem następuje nieznaczny spadek, ale roczna liczba małżeństw nie spada już poniżej 40. Kolejny wzrost nastąpił w roku 1898, ale największy skok przypada na lata 1902 (65 ślubów) i 1903 (71). Nie wiadomo, ile małżeństw zawarto w roku 1904, później natomiast - w ostatnich dwóch latach - ich liczba nieznacznie spadła ${ }^{69}$. Warto też odnotować, że największy jednoroczny wzrost miał miejsce w roku 1890, kiedy w porównaniu z poprzednim rokiem odnotowano o 18 ślubów więcej. Rok później - tj. w roku 1891 - doszło zaś do największego spadku liczby małżeństw, gdyż w porównaniu ze szczytowym rokiem 1890 odnotowano o 11 ślubów mniej. Jak widać zatem,

\footnotetext{
${ }^{69}$ Opuszczając na moment ramy chronologiczne, można dodać, że po 1906 roku następuje stabilizacja liczby zawieranych małżeństw, a następnie jej spadek, który trwa do końca I wojny światowej. Por. 1907-1918.
} 
liczba małżeństw zawieranych w urzędzie stanu cywilnego Gumieńce rosła z upływem lat. Chociaż wzrost ten był nieregularny, nie odnotowano wyraźnych momentów przełomowych.

Oprócz wzrostu bezwzględnej liczby małżeństw w obwodzie USC Gumieńce można było zaobserwować również wzrost współczynnika małżeństw ${ }^{70}$. W latach 1884-1887 wynosił on 7,1\%o (na 1000 ludności), w 1894-1897 już 7,6\%o, a pod koniec badanego okresu, w latach 1905-1906, przekroczył 8\%o. Współczynnik małżeństw wzrastał regularnie zarówno w Pomorzanach, jak i w pozostałych miejscowościach wchodzących w skład obwodu przez cały badany okres (nie uwzględniono Stobna, Krzekowa i majątku Eckersberg). Na podstawie tej tendencji można wnioskować, że z upływem lat w badanej populacji wzrastał odsetek ludzi młodych, a zwłaszcza odsetek ludności w wieku, w którym zawierano najwięcej małżeństw (tj. w wieku 20-29 lat).

Tabela 2. Współczynnik małżeństw (na 1000 ludności) w USC Gumieńce w latach 1884-1887, 1894-1897, 1905-1906

\begin{tabular}{lccc}
\hline \multicolumn{1}{c}{ Miejscowości } & $1884-1887$ & $1894-1897$ & $1905-1906$ \\
\hline Pomorzany & 7,3 & 7,7 & 7,9 \\
Pozostałe miejscowości & 7,0 & 7,4 & 8,3 \\
\hline Razem & 7,1 & 7,6 & 8,0 \\
\hline
\end{tabular}

Źródło: obliczenia własne na podstawie: Archiwum Państwowe w Szczecinie, Urząd Stanu Cywilnego Szczecin-Gumieńce, sygn. 18-45, 76, 81, 84; Gemeindelexikon [...] vom 1. Dezember 1885 [31], s. 29-37; Gemeindelexikon [...] vom 2. Dezember 1895 [31], s. 30-37; Gemeindelexikon [...] vom 1. Dezember 1905 [31], s. 118-125.

Chcąc sprawdzić, jak zmieniała się roczna liczba ślubów w poszczególnych miejscowościach okręgu urzędu stanu cywilnego, pod uwagę wzięte zostały miejsca zamieszkania nupturientek. Przyjęto bowiem, że ślub odbywa się najczęściej w miejscu zamieszkania panny młodej. Tak było na ogół również na terenie okręgu USC Gumieńce, gdzie zamieszkiwało 1266 kobiet (93\% nupturientek). Dla porównania mieszkało tutaj 1054 mężczyzn (78\% nupturientów). Najwięcej

${ }^{70}$ Do obliczenia tego parametru posłużono się liczbą mieszkańców we wszystkich miejscowościach obwodu USC Gumieńce, które leżały w granicach obwodu przez cały badany okres, to znaczy nie uwzględniono Stobna, Krzekowa i majątku Eckersberg (przede wszystkim dlatego, że w dwóch ostatnich miejscowościach zanotowana w ostatnim okresie liczba małżeństw była nieproporcjonalnie niska - prawdopodobnie było to spowodowane tym, że część ludności Krzekowa i majątku Eckersberg nadal zawierała małżeństwa w USC Niemierzyn). Dla lat 1885 i 1895 uwzględniono liczbę związków małżeńskich zawartych w roku poprzedzającym spis, roku spisu i dwóch latach po spisie (ponieważ dane spisowe dotyczyły stanu dla 1 grudnia danego roku). Dla roku 1905 uwzględniono rok spisu i jeden rok po spisie. 
małżeństw zawarto w najbardziej zaludnionej miejscowości - w Pomorzanach. Łącznie mieszkało tam 627 nupturientek. Średnio rocznie zawierano 20 ślubów, jednak wyraźny był trend wzrostowy. Najwięcej mieszkanek Pomorzan wyszło za mąż w roku 1903 (38), czyli wtedy, gdy odnotowano najwięcej nowych związków małżeńskich w całym okręgu. Najmniej ślubów (8) miało miejsce w latach 1876 i 1879. Analiza w przedziałach pięcioletnich wskazuje, że wzrost liczby ślubów w Pomorzanach był regularny, największy zaś w pięcioleciu 1881-1885, gdy liczba ślubów wyniosła 136,5\% z poprzedniego pięciolecia. Duży był także wzrost procentowego udziału kobiet z Pomorzan we wszystkich ślubach w okręgu USC Gumieńce. W pierwszym analizowanym pięcioleciu - 1876-1880 - stanowiły one 35,9\% wszystkich nupturientek, zaś w ostatnim pięcioleciu - 1901-1906 (bez 1904) $-54,1 \%$.

Zgoła odmienny jest przypadek samych Gumieniec, gdzie ślubów było coraz mniej. Tendencja ta nie jest łatwo dostrzegalna przy analizie rocznego rozkładu ślubów, jednak jest wyraźnie zauważalna przy podziale na pięciolecia. Od pięciolecia 1876-1880, gdy nupturientek z Gumieniec było 52, ich liczba spada regularnie aż do przedostatniego pięciolecia, gdy było ich zaledwie 29. Dopiero w ostatnim pięcioleciu kończy się regres i następuje wzrost liczby ślubów (do 41) ${ }^{71}$.

Wykres 3. Roczne liczby małżeństw według miejsca zamieszkania nupturientek w USC Gumieńce w latach 1876-1906 (bez roku 1904)

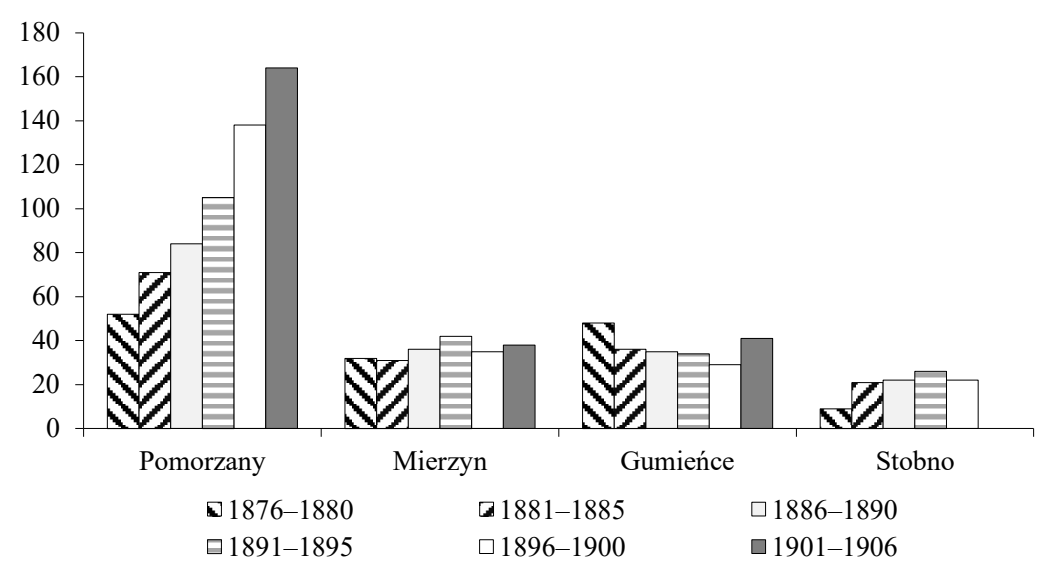

Źródło: obliczenia własne na podstawie: Archiwum Państwowe w Szczecinie, Urząd Stanu Cywilnego Szczecin-Gumieńce, sygn. 18-45, 76, 81, 84.

${ }^{71}$ Tendencja ta występuje również w przypadku nupturientów z Gumieniec. 
W żadnej innej badanej miejscowości nie następował tak wyraźny spadek liczby ślubów, a przypomnijmy, że liczba ludności Gumieniec nie zmieniała się w tym okresie ${ }^{72}$. W latach 1896, 1897 i 1900 za mąż wyszły tylko 3 kobiety, podczas gdy w Pomorzanach ponad 20. W 1896 roku ożenił się tylko jeden mężczyzna z Gumieniec, natomiast 20 z Pomorzan i 5 z Mierzyna. Trudno wytłumaczyć przyczyny tego zjawiska. Najprawdopodobniej było ono spowodowane nasileniem się migracji, zwłaszcza w przypadku młodych mieszkańców Gumieniec. Niewykluczone też, że spadek liczby małżeństw był przypadkowy i wynikał ze zbyt małej liczebności populacji. Na pewno jednak nie ma w przypadku Gumieniec mowy o takich procesach, jakie zachodziły w Pomorzanach, gdzie przyspieszona urbanizacja i industrializacja wsi wpłynęły na wzrost liczby mieszkańców i w konsekwencji wyraźny wzrost liczby ślubów. Podobnie było w Mierzynie i Stobnie, gdzie liczba ślubów nie zmieniała się istotnie z biegiem lat. Można natomiast zaobserwować, że z upływem czasu zwiększał się odsetek panien młodych spoza okręgu USC Gumieńce. Jeszcze wyraźniej tendencja ta zarysowuje się w przypadku mężczyzn, gdzie szczególnie zwiększała się liczba nupturientów ze Szczecina.

W 1875 roku najwięcej małżeństw zawarły mieszkanki Pomorzan i Mierzyna. Przez kolejne cztery lata dominowały pod tym względem Gumieńce i był to szczytowy okres dla tej miejscowości. Natomiast niezmiennie od 1880 do 1906 roku najwięcej ślubów miało miejsce $\mathrm{w}$ okręgu w Pomorzanach i jednocześnie odsetek małżeństw w tej miejscowości regularnie się powiększał.

Nowożeńców w Gumieńcach charakteryzowała ponadto jednolita struktura wyznaniowa. Zdecydowaną większość małżeństw zawierały między sobą osoby wyznania ewangelickiego (96,9\%). Zaledwie w przypadku 3,1\% małżeństw mężczyzna, kobieta lub oboje nowożeńców zadeklarowali wyznanie inne niż ewangelicyzm. Wśród nupturientów zamieszkałych w USC Gumieńce ewangelicy stanowili 97,4\%, wśród nupturientek odsetek ten sięgał 98,9\%.

Najliczniejszą mniejszość religijną stanowili katolicy. W aktach stanu cywilnego odnotowano łącznie 37 osób tego wyznania, w tym 30 osób zamieszkałych w obwodzie USC Gumieńce. Katolikami częściej byli mężczyźni (1,9\% nupturientów zamieszkałych w obwodzie USC) niż kobiety $(0,8 \%)$, najczęściej mieszkali w Gumieńcach (8 nupturientów i 6 nupturientek). Małżeństwa zawierali na ogół z ewangelikami, tylko w 6 przypadkach nowożeńcy byli wyznawcami katolicyzmu. W obwodzie USC Gumieńce odnotowano też 9 nowożeńców deklarujących inne niż ewangelicyzm wyznanie protestanckie (Kościół ewangelicko-luterański, staroluterański, niemiecko-katolicki) oraz 3 osoby wyznania żydowskiego.

${ }^{72}$ Gemeindelexikon [...] vom 1. Dezember 1885 [31], s. 29-37; Gemeindelexikon [...] vom 2. Dezember 1895 [31], s. 30-37; Gemeindelexikon [...] vom 1. Dezember 1905 [31], s. 118-125. 


\section{Sezonowość małżeństw}

W badaniach opartych na rejestracji metrykalnej szczególną wagę przykłada się do analizy miesięcznej i tygodniowej sezonowości małżeństw. Irena Gieysztorowa wymienia ją jako jedną z podstawowych wartości otrzymywanych przy badaniach małżeństw ${ }^{73}$. Zagadnienie to pojawia się właściwie we wszystkich badaniach demograficznych opartych na parafialnych księgach małżeństw lub aktach stanu cywilnego. Wszędzie też podkreśla się jego znaczenie. Wybór miesiąca i dnia ślubu ukazuje bowiem pewne cechy obyczajowości danego społeczeństwa, uwzględnia uwarunkowania gospodarczo-społeczne i wyznaniowe.

Roczna sezonowość zawierania małżeństw wynikała zazwyczaj z dwóch czynników: przepisów kościelnych oraz charakteru lokalnej gospodarki ${ }^{74}$. Kościół ewangelicki początkowo - podobnie jak Kościół katolicki - zabraniał udzielania ślubów w czasie Wielkiego Postu i Adwentu. W 1868 roku zakaz ten ograniczono do dwóch ostatnich tygodni Wielkiego Postu i ostatniego tygodnia Adwentu ${ }^{75}$. Względy ekonomiczne były w głównej mierze związane $\mathrm{z}$ kalendarzem prac rolnych. Unikano organizowania ślubów w miesiącach letnich, czyli w czasie najbardziej intensywnych prac polowych, a za najbardziej korzystny czas uważano miesiące jesienne, kiedy prace były już zakończone, a możliwości finansowe większe. Także społeczeństwo miejskie skłaniało się do zawierania ślubów w okresie jesienno-zimowym, wówczas bowiem obowiązywały najniższe ceny żywności ${ }^{76}$. Te dwie podstawowe determinanty (tzn. zakaz zawierania małżeństw w okresach postnych oraz kalendarz prac polowych) zostały potwierdzone właściwie we wszystkich badaniach rocznej sezonowości ślubów na ziemiach polskich, bez względu na zakres chronologiczny ${ }^{77}$.

W przeciwieństwie do większości parafii i okręgów stanu cywilnego na ziemiach polskich w USC Gumieńce liczba zawieranych małżeństw w ciągu roku rozkładała się stosunkowo równomiernie. Mimo to można wskazać miesiące, które były wybierane nieco częściej od innych. Najwięcej - 209 małżeństw - zawarto w listopadzie, co stanowi o $87 \%$ więcej od przeciętnej miesięcznej liczby małżeństw (w miejscowościach innych niż Pomorzany odchylenie od średniej

${ }^{73}$ I. Gieysztorowa, Wstęp do demografii staropolskiej [22], s. 250.

${ }^{74}$ R. Gaziński i in., Śluby w parafii [2], s. 49.

${ }^{75}$ Tamże.

${ }^{76}$ W. Pasieka, Śluby w parafii opolskiej [67], s. 41.

${ }^{77} \mathrm{Na}$ ten temat pisano między innymi w: Anna Czop, Ruch naturalny ludności w parafii juncewskiej w latach 1801-1870 (na podstawie ksiag metrykalnych), PDP 29, 2010, s. 108; Z. Klotzke, Ludność obwodu [5]; W. Pasieka, Śluby w parafii opolskiej [67], s. 47; Cezary Kuklo, Próba analizy demograficznej rejestracji metrykalnej ślubów parafii Trzcianne w I połowie XVIII wieku, PDP 13, 1981, s. 108; Anna Siłuch, Rejestracja metrykalna ślubów w parafii Ostrów Mazowiecka w XVII w., PDP 14, 1983, s. 88. 
liczby małżeństw wyniosło 134\%). Kolejne miejsca pod względem popularności zajęły dwa sąsiednie miesiące: grudzień (167) i październik (143). Podobnie było chociażby w nieodległej parafii Jasienica, gdzie listopad również był najchętniej wybieranym miesiącem, a październik i grudzień ustępowały styczniowi i lutemu ${ }^{78}$. Bardzo podobne wyniki - stwierdzające popularność listopada oraz października i grudnia - uzyskano dla XIX-wiecznej parafii Juncewo, śląskiej parafii Rząśnik, strefy podmiejskiej Rzeszowa oraz mikroregionu Czacz (XVI$\mathrm{XX}$ wiek $)^{79}$. Liczne inne badania demograficzne wykazały popularność listopada $\mathrm{w}$ wyborze miesiąca ślubu ${ }^{80}$.

W okręgu USC Gumieńce najbardziej popularny był okres jesienny i jesienno-zimowy, co ilustruje wskaźnik sezonowości. Bardzo mało małżeństw zawierano w styczniu i lutym. Styczeń jest w ogóle najmniej popularny spośród wszystkich miesięcy - w ciągu 31 lat w miesiącu tym zawarto jedynie 66 ślubów (44\% mniej od przeciętnej miesięcznej liczby małżeństw). W pierwszym dziesięcioleciu trzecie miejsce pod względem popularności zajmował marzec, w kolejnych latach jednak miesiąc ten wybierano coraz rzadziej. Odwrotnie było w przypadku kwietnia, maja i czerwca. Po 1886 roku były one jednymi z najchętniej wybieranych miesięcy. Można to tłumaczyć faktem, że miesiące te przypadają na okres pomiędzy Wielkim Postem a intensyfikacją prac rolnych. Pozostałe trzy miesiące letnie - lipiec, sierpień i wrzesień - w całym badanym okresie cieszyły się niewielką popularnością nupturientów. Może to świadczyć o wciąż utrzymujących się zwyczajach, charakterystycznych dla kultury wiejskiej.

Łącznie 38,2\% wszystkich małżeństw zawarto w miesiącach jesiennych w październiku, listopadzie i grudniu. W półroczu jesienno-zimowym zawarto 57,1\% ślubów. Oznacza to, że miesiące wiosenne i letnie cieszyły się nieco mniejszym zainteresowaniem nupturientów. Różnice nie były jednak duże. W porównaniu z innymi badaniami, zwłaszcza tymi, które dotyczyły akt metrykalnych

${ }^{78}$ R. Gaziński i in., Śluby w parafii [2], s. 53.

${ }^{79}$ A. Czop, Ruch naturalny ludności [77], s. 108; Stanisław Borowski, Procesy demograficzne w mikroregionie Czacz w latach 1598-1975, PDP 9, 1976, s. 151; Krystyna Górna, Sezonowość ruchu naturalnego ludności ewangelickiej w parafii Rzaśnik w latach 1794-1874, „Śląski Kwartalnik Historyczny «Sobótka»" 39, 1984, nr 4, s. 564-565; Sabina Rejman, Ludność podmiejska Rzeszowa w latach 1784-1880, Rzeszów 2006, s. 160.

${ }^{80}$ Por. Z. Klotzke, Ludność obwodu [5], s. 79; Jan Chłosta, Świętowanie na Warmii w końcu XIX i na poczatku XX wieku, [w:] Życie codzienne na dawnych ziemiach pruskich, obchody rocznicowe $i$ świateczne, red. Stanisław Achremczyk, Olsztyn 2004, s. 66; Edmund Piasecki, Ludność parafii bejskiej (woj. kieleckie) w świetle ksiag metrykalnych z XVIII-XX w., Warszawa-Wrocław 1990, s. 106; C. Kuklo, Próba analizy [77], s. 108-109; Hanna Górecka, Alicja Janeczko, Ruch naturalny ludności parafii Stawięcice w latach 1804-1870, „Studia Śląskie. Seria Nowa” 40, 1982, s. 276; Teresa Krotla, Ludność parafii bielawskiej w latach 1766-1830 (na podstawie ksiag metrykalnych), „Śląski Kwartalnik Historyczny «Sobótka»" 46, 1992, nr 4, s. 422; Hanna Kurowska, Gubin i jego mieszkańcy, Zielona Góra 2010, s. 128; Jerzy Spychała, Ruch naturalny ludności Oleśnicy w latach 1875-1885, „Śląski Kwartalnik Historyczny «Sobótka»” 46, 1991, nr 4, s. 489-490. 
z XVII i XVIII wieku, liczby ślubów w poszczególnych miesiącach rozkładają się stosunkowo równomiernie ${ }^{81}$.

Tabela 3. Wybór miesiąca ślubu w okręgu USC Gumieńce w okresach pięcioletnich (okres 1875-1880 - sześcioletni, okres 1901-1906 - bez roku 1904)

\begin{tabular}{lrrrrrrrrrrrrr}
\hline \multicolumn{1}{c}{ Okres } & I & II & III & IV & V & VI & VII & VIII & IX & X & XI & XII & $\begin{array}{r}\text { Ra- } \\
\text { zem }\end{array}$ \\
\hline $1875-1880$ & 11 & 11 & 20 & 16 & 17 & 11 & 13 & 11 & 10 & 17 & 32 & 25 & 194 \\
$1881-1885$ & 8 & 12 & 17 & 8 & 17 & 9 & 11 & 7 & 8 & 17 & 33 & 22 & 169 \\
$1886-1890$ & 8 & 15 & 11 & 17 & 19 & 13 & 14 & 5 & 13 & 26 & 37 & 29 & 207 \\
$1891-1895$ & 12 & 10 & 20 & 17 & 21 & 16 & 12 & 14 & 13 & 23 & 37 & 32 & 227 \\
$1896-1900$ & 10 & 17 & 18 & 19 & 30 & 23 & 18 & 13 & 17 & 25 & 34 & 31 & 255 \\
$1901-1906$ & 17 & 12 & 27 & 31 & 33 & 26 & 20 & 22 & 18 & 35 & 36 & 28 & 305 \\
\hline Razem & 66 & 77 & 113 & 108 & 137 & 98 & 88 & 72 & 79 & 143 & 209 & 167 & 1357 \\
\hline
\end{tabular}

Źródło: obliczenia własne na podstawie: Archiwum Państwowe w Szczecinie, Urząd Stanu Cywilnego Szczecin-Gumieńce, sygn. 18-45, 76, 81, 84.

Pewne różnice w wyborze miesiąca ślubu można zauważyć przy porównaniu poszczególnych miejscowości (podobnie jak przy analizie statystyk rocznych wziąłem pod uwagę miejsca zamieszkania nupturientek). W całym okręgu USC Gumieńce najchętniej wybieranym miesiącem był listopad. Na przykładzie wykresu wskaźnika sezonowości widać, iż przewaga listopada nad pozostałymi miesiącami była charakterystyczna dla innych niż Pomorzany miejscowości obwodu USC Gumieńce. Liczba zawartych w tym miesiącu związków małżeńskich wynosiła dla tych miejscowości ponad 230\% średniej miesięcznej. W Pomorzanach było to niespełna $140 \%{ }^{82}$.

W podziale na miejscowości przede wszystkich widać zatem, że w miejscowościach o rolniczym charakterze różnice w popularności poszczególnych miesięcy były większe niż w robotniczych osiedlach Pomorzan, gdzie sezonowość odgrywała znacznie mniejszą rolę $e^{83}$. Różnice pojawiają się również w przypadku popularności drugiego miesiąca. W Pomorzanach był to maj (69 ślubów), jednak tylko nieznacznie bardziej popularny niż grudzień (68) i październik (64).

${ }^{81}$ Na przykład w XVII wieku w parafii Ostrów Mazowiecka w miesiącach jesienno-zimowych zawierano od 72 do $78 \%$ ślubów, a w XVIII wieku w parafii Szaradowo ponad 80\% ślubów. Por. A. Siłuch, Rejestracja metrykalna ślubów [77], s. 88; Marek Górny, Rejestracja metrykalna parafii Szaradowo z XVIII wieku, PDP 18, 1991, s. 130.

${ }^{82} \mathrm{~W}$ badanym okresie na Pomorzu Zachodnim najczęściej małżeństwa zawierano w kwietniu i październiku. Podobne wahania sezonowości małżeństw (popularność maja i listopada) odnotowano dla Greifswaldu w latach 1886-1899. Por. D.K. Chojecki, Od społeczeństwa tradycyjnego [1], s. 170-173.

${ }^{83}$ Podobne tendencje odnotowano dla Szczecina. Tamże. 
Najmniej popularny był styczeń (tylko 24 śluby). Również w Gumieńcach pary najchętniej wybierały listopad (36 ślubów), a w drugiej kolejności maj (27). Najmniej popularny był wrzesień (8 ślubów). Inaczej było w Mierzynie i Stobnie. W obu tych miejscowościach zdecydowanie najwięcej ślubów odbywało się w listopadzie (kolejno: 55 i 23), a drugie miejsce zajmował grudzień (43 i 16). Maj w ogóle nie było popularny i był jednym z rzadziej wybieranych miesięcy. W Mierzynie jednak najmniej małżeństw zawarto we wrześniu (7), w Stobnie zaś w lipcu (3).

Tabela 4. Wskaźnik sezonowości miesięcznej małżeństw w USC Gumieńce w latach 1875-1906 (bez roku 1904) - w podziale na Pomorzany i pozostałe miejscowości

\begin{tabular}{lcccccccccccc}
\hline $\begin{array}{c}\text { Miejsce } \\
\begin{array}{c}\text { zamieszkania } \\
\text { nupturientki }\end{array}\end{array}$ & I & II & III & IV & V & VI & VII & VIII & IX & X & XI & XII \\
\hline $\begin{array}{l}\text { Pomorzany } \\
\begin{array}{l}\text { Pozostałe } \\
\text { miejscowości }\end{array}\end{array}$ & 45,7 & 67,1 & 103,3 & 99,8 & 132,4 & 109,3 & 92,0 & 70,7 & 87,9 & 122,3 & 139,5 & 130,0 \\
\hline Razem & 55,8 & 71,9 & 99,2 & 78,3 & 102,7 & 67,3 & 65,6 & 56,3 & 56,3 & 129,4 & 233,9 & 170,6 \\
\hline
\end{tabular}

Źródło: obliczenia własne na podstawie: Archiwum Państwowe w Szczecinie, Urząd Stanu Cywilnego Szczecin-Gumieńce, sygn. 18-45, 76, 81, 84.

Wykres 4. Wskaźnik sezonowości miesięcznej małżeństw w USC Gumieńce w latach 1875-1906 (bez roku 1904) - w podziale na Pomorzany i pozostałe miejscowości

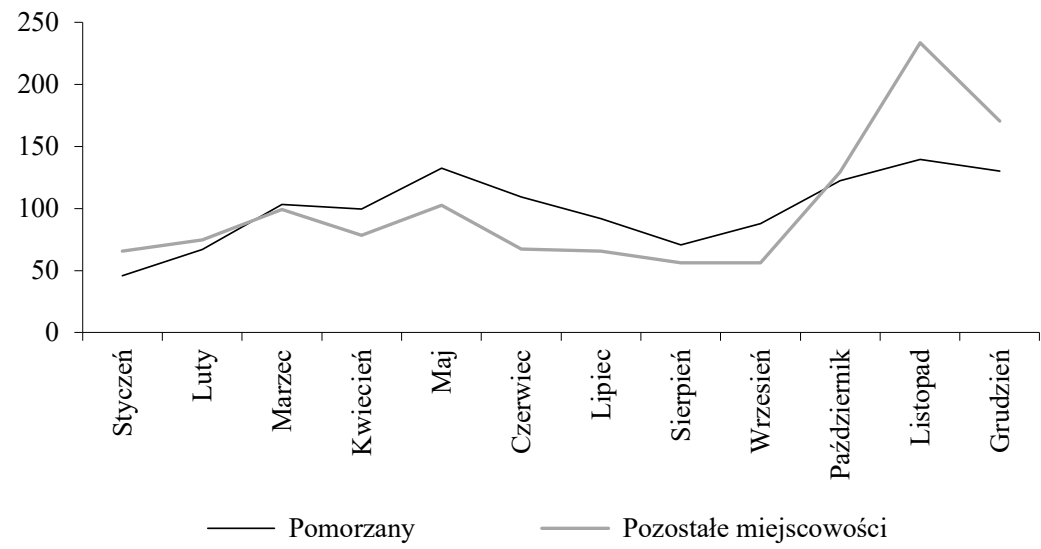

Źródło: obliczenia własne na podstawie: Archiwum Państwowe w Szczecinie, Urząd Stanu Cywilnego Szczecin-Gumieńce, sygn. 18-45, 76, 81, 84. 
Jeśli chodzi o strukturę zawodową nupturientów, w miesiącach jesiennych (październik, listopad i grudzień) najchętniej żenili się robotnicy oraz przedstawiciele kategorii „,pozostałe”, czyli w większości reprezentanci zawodów o niższym prestiżu (m.in. dozorcy, woźnice, parobkowie). Wśród robotników najbardziej popularnym miesiącem na zawarcie małżeństwa okazał się listopad, następnie grudzień i październik. Najrzadziej żenili się latem, czyli w lipcu i sierpniu. Różnice w popularności poszczególnych miesięcy były stosunkowo wyraźne. Robotnicy najczęściej zawierali związki małżeńskie w półroczu zimowym. W miesiącach od października do marca odnotowano łącznie 60,3\% wszystkich ślubów.

Podobne tendencje można zaobserwować w przypadku kategorii właścicieli. W tej grupie znaczny odsetek stanowili właściciele ziemscy, czyli osoby, których tryb życia był w znacznym stopniu zdeterminowany przez kalendarz prac polowych, a zasoby ekonomiczne uzależnione od jakości zbiorów. Te czynniki miały realny wpływ na preferencje $\mathrm{w}$ wyborze miesiąca ślubu. Właściciele najchętniej żenili się w październiku i w listopadzie. Żaden z nich natomiast nie zdecydował się na zawarcie małżeństwa w sierpniu. W półroczu zimowym odbyło się łącznie 63\% ślubów właścicieli.

Zupełnie inne preferencje w wyborze miesiąca ślubu charakteryzowały dwie pozostałe kategorie społeczno-zawodowe - inteligencję i urzędników oraz rzemieślników. W obu tych grupach nupturienci nieznacznie częściej wybierali na zawarcie małżeństwa miesiące letnie. W grupie inteligencji i kadry urzędniczej (czyli zawodów typowo miejskich, o wyższych prestiżu) najbardziej popularnym miesiącem okazał się listopad (10 ślubów), a następnie październik (9 ślubów). Trzecie miejsce pod względem preferencji zajęły kwiecień i maj (7 ślubów). Najrzadziej reprezentanci tej grupy żenili się na początku roku. W okresie od stycznia do marca odnotowano tylko 5 związków małżeńskich.

Prawie we wszystkich kategoriach społeczno-zawodowych najbardziej popularnym miesiącem na zawarcie małżeństwa okazał się listopad. Jedynym wyjątkiem okazali się rzemieślnicy, którzy najczęściej żenili się w grudniu (37 ślubów). Popularniejszy od listopada (28 ślubów) okazał się jeszcze maj (30 ślubów) oraz lipiec (29 ślubów). Zwłaszcza ten ostatni miesiąc był szczególnie rzadko wybierany przez reprezentantów innych kategorii społeczno-zawodowych.

Podstawowa różnica w rocznej sezonowości ślubów pod względem struktury społeczno-zawodowej to większa popularność miesięcy zimowych (głównie od listopada do marca) pośród zawodów związanych z rolnictwem i kapitałem ziemskim. W zawodach typowo miejskich można zauważyć, że im wyższa pozycja społeczna, tym mniejsza popularność miesięcy jesienno-zimowych i rosnąca popularność miesięcy wiosenno-letnich (od kwietnia do października). Pomocniczo wyłoniono również grupę nupturientów związanych z rolnictwem - głównie właścicieli ziemskich oraz pracowników rolnych (jednak bez robotników, 
w przypadku których nie było możliwe zidentyfikowanie miejsca i charakteru wykonywanej pracy). W grupie tej najczęściej wybieranym miesiącem był listopad (12 ślubów), a następnie marzec i grudzień (8 ślubów). Pośród miesięcy letnich nupturienci związani z rolnictwem nieco częściej żenili się tylko we wrześniu (7 ślubów). W półroczu zimowym (od października do marca) odnotowano łącznie $65 \%$ związków małżeńskich.

Jak widać zatem, praca w rolnictwie wpływała w znacznym stopniu na wybór miesiąca ślubu. Praca w zawodach mieszczańskich umożliwiała większą swobodę wyboru terminu ślubu, przy czym w zawodach umożliwiających wyższe zarobki tendencja ta była bardziej wyraźna. Przyczyną tego prawdopodobnie może być pochodzenie wiejskie ludności robotniczej przedmieść Szczecina oraz większy wpływ cen żywności na sezonowość ślubów w tej klasie zawodowej. Niestety, przeważający odsetek ewangelików i zbyt mała liczba wyznawców innych religii w badanej populacji uniemożliwiły zbadanie rocznej sezonowości ślubu w zależności od wyznania.

W demograficznych badaniach ślubów bardzo często analizowano również sezonowość tygodniową. Jednakże wybór źródeł, jakimi są akta stanu cywilnego, niejako deprecjonuje wartość tej statystyki. Wybór dnia tygodnia ślubu najczęściej odzwierciedlał religijną i kulturalną obyczajowość danej społeczności. Nie wiadomo jednak na pewno, czy śluby cywilne odbywały się tego samego dnia co uroczystości kościelne i wesela, czy może z pewnym wyprzedzeniem. Nie wiadomo także, na ile decydowały o tym regionalne tradycje, a na ile po prostu tryb pracy urzędu.

W całym badanym okresie najwięcej ślubów w urzędzie stanu cywilnego zawarto w czwartki (479), następnie w soboty (403) i poniedziałki (313). Pozostałe dni były znacznie mniej popularne, przy czym ostatnie miejsce zajmowała niedziela (zaledwie 6 wpisów w ciągu 31 lat). Trudno spekulować, czy przyczyną tego była lokalna obyczajowość, względy religijne, czy może po prostu fakt, że urząd był w niedzielę zamknięty. Wybór dnia tygodnia ślubu zmieniał się istotnie wraz z upływem lat. O ile liczba ślubów zawieranych w poniedziałki nie zmieniała się w sposób znaczący, o tyle czwartek regularnie tracił, a sobota zyskiwała popularność. W latach 1875-1880 w czwartki odnotowano 134 śluby (69\%), a w sobotę tylko 1. W okresie 1901-1906 (bez roku 1904) w soboty odbyły się już 182 śluby (60\%), a w czwartki zaledwie 27.

Popularność czwartku jako dnia, w którym odbywało się najwięcej ślubów cywilnych, mogła nie być przypadkowa. Ten sam dzień tygodnia najczęściej wybierali nupturienci z pobliskiej Jasienicy, gdzie w latach 1778-1880 zawarto w czwartki łącznie $48 \%$ związków małżeńskich ${ }^{84}$. Kolejne miejsca pod wzglę-

${ }^{84}$ R. Gaziński i in., Śluby w parafii [2], s. 50. 
dem popularności zajmowały w Jasienicy sobota i niedziela, jednak odsetek ślubów zawartych w tych dniach był już znacznie niższy.

W Gumieńcach zdarzały się miesiące, w których zawierano szczególnie dużo ślubów. Najwięcej, bo 13 ślubów odnotowano w listopadzie 1902 roku. Rekordowy był także grudzień roku 1889 i marzec 1903 roku - zawarto wówczas po 11 ślubów. Bardzo często udzielano kilku ślubów jednego dnia, najczęściej dwu lub trzech. Najwięcej - pięć ślubów jednego dnia, udzielono 15 listopada 1902 roku. Dane z 1875 roku ukazują, że ceremonia i wpis do księgi trwały na ogół od pół godziny do pełnej godziny (tylko w 1875 roku zapisywano dokładne godziny ślubów).

Analiza liczebności i sezonowości małżeństw zawartych w latach 1875-1906 w obwodzie USC Gumieńce, w konfrontacji z danymi dotyczącymi wzrostu zaludnienia oraz rozwoju infrastruktury mieszkaniowej, przemysłowej i społecznej w aglomeracji szczecińskiej, pozwoliła przynajmniej częściowo odpowiedzieć na postawione pytania, problemy badawcze. Zaawansowane stadium transformacji demograficznej na Pomorzu Zachodnim oraz postępująca industrializacja i urbanizacja zespołu miejskiego Szczecina w ostatnim ćwierćwieczu XIX wieku znalazły wyraźne odzwierciedlenie w strukturze małżeństw zawieranych w urzędzie stanu cywilnego w Gumieńcach. W badanym okresie odnotowano korelację pomiędzy wzrostem liczby mieszkańców a wzrostem rocznej liczby małżeństw. Jednocześnie wykazano, że tendencja ta właściwa była przede wszystkim dla Pomorzan, gdzie w latach 1971-1905 odnotowano blisko czterokrotny wzrost liczby mieszkańców i dwukrotny wzrost liczby obiektów mieszkalnych, a jednocześnie regularnie wzrastała liczba zawieranych małżeństw. Wyraźnie niższy wzrost liczby małżeństw w pozostałych miejscowościach obwodu USC Gumieńce (a nawet nieznaczny spadek w samych Gumieńcach) związany był ze znacznie mniejszą niż w przypadku Pomorzan skalą migracji do Gumieniec, Mierzyna i Stobna. Wzrost współczynnika małżeństw w całym obwodzie USC świadczy z kolei o wzroście liczebności grup wiekowych najczęściej zawierających małżeństwa, to jest ludności w wieku 20-29 lat. Struktura wiekowa nupturientów zostanie wszakże dogłębnie przeanalizowana w II części artykułu.

Różne tempo dynamiki rozwoju społeczno-gospodarczego poszczególnych miejscowości obwodu USC Gumieńce zaobserwowano również w analizie sezonowości miesięcznej małżeństw. Choć we wszystkich miejscowościach najpopularniejszym miesiącem zamążpójścia był listopad, to większe wahania wskaźnik sezonowości miesięcznej wykazywał dla Gumieniec, Mierzyna i Stobna oraz dla nupturientów zatrudnionych $\mathrm{w}$ zawodach związanych z rolnictwem. Wahania sezonowości miesięcznej systematycznie malały w całym badanym okresie, 
a liczebność ślubów w poszczególnych miesiącach rozkładała się stosunkowo równomiernie $\mathrm{w}$ porównaniu $\mathrm{z}$ innymi badaniami demograficznymi ludności polskiej w XIX wieku. Najniższy wskaźnik sezonowości małżeństw charakteryzował robotnicze Pomorzany i grupę społeczno-zawodową rzemieślników, co świadczy o malejącej roli uwarunkowań religijnych i ekonomicznych, właściwych dla społeczeństw przedindustrialnych.

\section{Entering into Matrimony in the Suburbs of Szczecin in the Light of Marriage Records of the Gumieńce (German: Scheune) Register Office in the Years 1875-1906.}

Part 1: Annual Numbers of Marriages and the Seasonality of Matrimonies

\section{Summary}

In the last quarter of the 19th century in Western Pomerania some demographic and socio-economic processes took place at the same time: stabilisation of death rate and a decrease in reproduction, an agricultural crisis and a migration fever. After pulling down the city walls Szczecin (German: Stettin) started spreading in all directions. The main objective of the research has been to grasp the process of demographic changes, which were parallel to the socio-economic development of the Szczecin suburbs, as well as to present the effects of the accelerated urbanisation and industrialisation of Pomorzany (German: Pommerens-dorf), one of the Szczecin suburbs, in comparison to neighbouring settlements, where such changes occurred not so fast or even did not happen at all. For that reason on the basis of the Register Office's certificates a list was made, which included 1357 matrimonies contracted in the years 1875-1906 within the jurisdiction of the Gumieńce Register Office (German: Standesamtbezirk Scheune). The aggregate method has been used to determine the annual numbers of matrimonies, seasonality of matrimonies and an average age of newly-weds. The research indicates that in the years 1875-1906, parallel to an increase of the inhabitants, in Pomorzany the number of contracted matrimonies and the matrimonial rate were increasing regularly, whereas the annual seasonality rate was decreasing. In more remote settlements, in Gumieńce, Mierzyn (Möhringen) and Stobno (Stöven) agriculture was dominant, the number of matrimonies did not change significantly, and the annual seasonality rate had big fluctuations from month to month.

Keywords: marriages, Register Office's certificates, newly-weds, prospective spouses, seasonality, Western Pomerania, Szczecin, Gumieńce 